\title{
Metastasis of lung cancer to bone of the finger: a case report
}

\section{Przerzut raka płuca do kości palca - opis przypadku}

\author{
Andrzej Żyluk ${ }^{\bowtie}$, Piotr Janowski, Zbigniew Szlosser \\ Pomorski Uniwersytet Medyczny w Szczecinie, Klinika Chirurgii Ogólnej i Chirurgii Ręki, ul. Unii Lubelskiej 1, 71-252 Szczecin \\ $\triangle$ azyluk@hotmail.com
}

\begin{abstract}
Introduction: Metastases of malignant neoplasms to the hand and wrist are rare. The lung, breast and kidneys are more common sites of primary lesions that metastasize in the hand. Phalanges are more commonly involved than the metacarpal and wrist. Case report: We report the case of a metastatic tumour involving the distal phalanx of the little finger originating from lung cancer in a patient with a history of advanced neoplastic disease (stage III B). Lung cancer was diagnosed approximately 10 months prior to the occurrence of metastasis. The tumour in
\end{abstract}

the finger grew slowly, causing enlargement of the distal phalanx, causing no pain and not interfering with the hand function. The diagnosis was made based on X-ray performed due to occasional trauma of the involved finger. Treatment of the metastatic tumour consisted in amputation of the finger. After healing of the stump the patient was referred to further palliative, oncologic care.

Keywords: lung cancer; metastasis to the bone; metastasis to the hand.

\begin{abstract}
ABSTRAKT
Wstęp: Przerzuty nowotworowe do ręki są bardzo rzadkie. Najczęstszym źródłem takich przerzutów są raki płuca, sutka i nerek, a najczęstszą lokalizacją przerzutów są paliczki dalsze palców, kości śródręcza i nadgarstka.

Opis przypadku: W pracy przedstawiono przypadek przerzutu raka płuca do kości paliczka dalszego małego palca u pacjenta z zaawansowanym (stadium III B) rakiem niedrobnokomórkowym płuca zdiagnozowanym ok. 10 miesięcy przed
\end{abstract}

rozpoznaniem przerzutu. Guz małego palca powiększał się powoli, powodując powiększenie się paliczka dalszego, był niebolesny i nie zaburzał czynności ręki. Rozpoznanie zostało ustalone na podstawie zdjęcia RTG wykonanego po przypadkowym urazie małego palca. Leczenie przerzutu polegało na amputacji małego palca, po której pacjent został skierowany do dalszego, paliatywnego leczenia onkologicznego.

Słowa kluczowe: rak płuca; przerzut do kości; przerzut do ręki.

\section{INTRODUCTION}

The involvement of bone and soft tissue of the hand in metastatic tumours is rare (about $0.1 \%$ incidence), and skeletal metastases are more common than to the soft tissue. The most common origin of metastasis to the hand is lung, followed by kidney, breast, colon, and stomach cancers $[1,2]$. The typical presentation of hand metastasis includes swelling above the involved bone, enlargement of the finger, or a palpable mass. In the early stage it may be only an occasional pain in the hand or wrist, mild swelling or dysfunction. In some cases the occurrence of a metastatic lesion may outstrip (be present earlier) clinical manifestation of the primary neoplasm [3]. Plain X-ray is usually enough for diagnosis in most cases, but small or occult lesions may require CT, MRI or ${ }^{99 \mathrm{~m}} \mathrm{Tc}$ bone scintigraphy [3, 4].

We report the case of a metastatic tumour involving the distal phalanx of the little finger originating from lung cancer in a patient with a history of advanced neoplastic disease.

\section{CASE REPORT}

A 66-year-old male patient was referred to the authors' institution due to enlargement of the distal phalanx of the little finger of his left (non-dominant) hand, which the patient noticed approximately 5 months before admission. The diameter of the distal phalanx slowly increased but the patient did not seek medical advice, as the tumour grew slowly, caused no pain, and did not interfere with hand function. Two weeks before presentation he sustained blunt trauma of the little finger. An X-ray performed in emergency showed a lytic lesion involving the whole distal phalanx of the finger, which was the direct cause of surgical referral. At presentation the patient was in good general condition, adequate for his age and primary disease. Examination of the left hand revealed enlargement of the distal phalanx of the little finger with deformation and a small ulceration near the nail plate (Fig. 1). Data from the patient's notes revealed a history of advanced (stage III B) non-small cell lung cancer diagnosed 10 months before. The patient underwent 

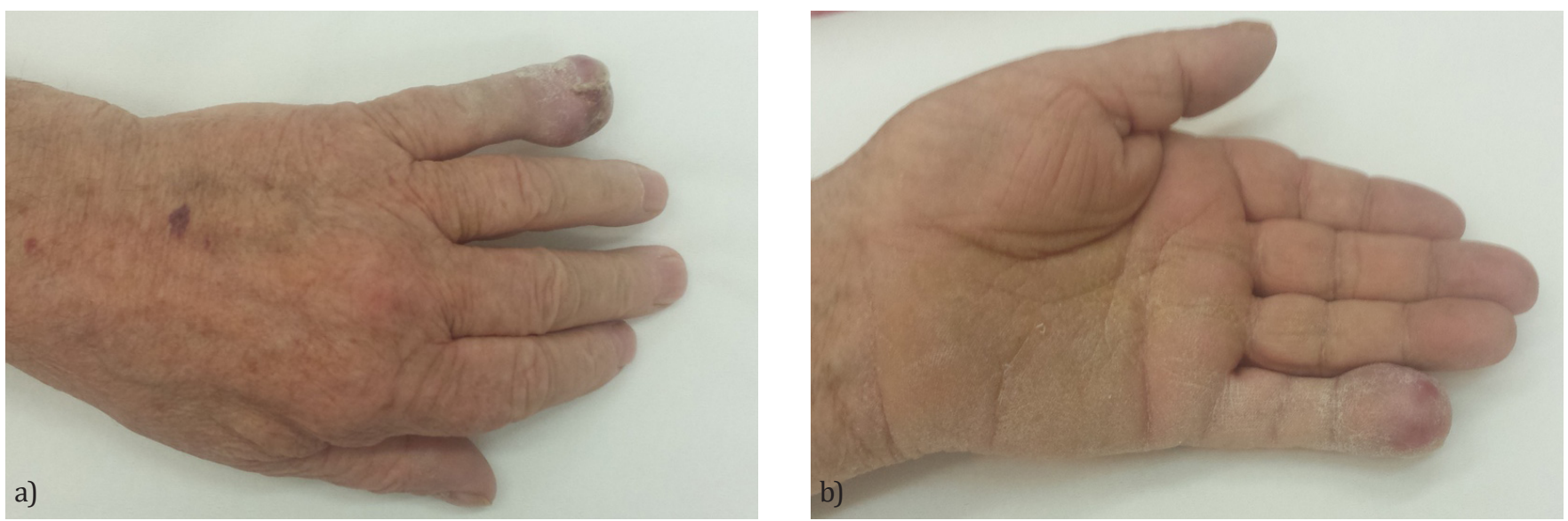

FIGURE 1. Appearance of the finger at presentation: a) dorsal side; b) palmar side

a course of chemotherapy, as the lung tumour was irresectable. Considering the oncological history and the typical radiological pattern of the lesion, the diagnosis of metastatic tumour of the bone of the distal phalanx was made. After obtaining the patient's informed consent, an amputation of the little finger at the level of the proximal interphalangeal joint was performed. The post-operative course was uneventful and the wound healed primarily. Histological and histochemical examination of the specimen showed $\mathrm{CK}_{7}(+), \mathrm{CK} 20(-), \mathrm{p} 63(-)$, HMB45(-), TTF1 $(+)$, confirming metastasis of the lung adenocarcinoma. Surgical excision was found to be complete. After healing of the stump the patient was referred for further palliative, oncological care. Four months after amputation of the finger the patient died due to progression of the disease.

\section{DISCUSSION}

The presented case is the second example of metastasis of organ malignancy to the hand seen in the authors' institution. Recently, we reported the case of a neglected, large metastatic tumour involving a patient's left wrist and metacarpus, originating from renal cancer, which appeared 2 years prior to the diagnosis of the primary neoplasm [3]. In the presented case, the interval between diagnosis of the lung cancer and its metastasis in the finger was approximately 6 months, which would suggest the bony lesion being present at the time of the diagnosis of the primary neoplasm.

The literature shows several reports on metastases of malignant tumours to the hand, mostly to bones. However, compared to metastases to other organs and tissues, they are extremely rare. Amadio and Lombardi reported 9 cases of hand metastases among 75,773 patients (0.01\%) diagnosed with malignant neoplasm of various origins [5]. A review of the literature shows the most common site of metastatic deposits to the hand is the distal phalanx, followed by metacarpal and carpal bones (17\% either), and the more frequent involvement of men than women $[1,2,4]$. The expected survival for patients with malignant metastases to the hand is poor, usually not longer than 6 months, as in the presented case $[1,6,7]$. Treatment includes local excision of the tumour, or amputation if localized in a finger. As the prognosis is generally poor, reconstructive surgery is not indicated. If the tumour is sensitive, radiotherapy or chemotherapy may be appropriate.

\section{REFERENCES}

1. Sur YJ, Kang YK, Bahk WJ, Chang DK, Rhee SK. Metastatic malignant tumour in the hand. J Plast Surg Hand Surg 2011;45(2):90-5. doi: 10.3109/2000656X.2011.556224.

2. Afshar A, Ayatollahy H, Lotfinejad S. A rare metastasis in the hand: a case of cutaneous metastasis of choriocarcinoma to the small finger. J Hand Surg [Am] 2007;32(3):393-6

3. Żyluk A, Janowski P. Metastasis of renal cancer to the wrist and hand: a case report. Pomeranian J Life Sci 2016;62(2):56-8. doi: 10.21164/ pomjlifesci.152.

4. Ozcanli H, Ozdemir H, Ozenci AM, Söyüncü Y, Aydin AT. Metastatic tumors of the hand in three cases. Acta Orthop Traumatol Turc 2005;39:445-8.

5. Amadio PC, Lombardi RM. Metastatic tumours of the hand. J Hand Surg [Am] 1987;12(2):311-6.

6. French FP, Murray PM, Perdikis G. Extensive cutaneous metastatic breast carcinoma of the hand and upper extremity: a case report. J Hand Surg [Am] 2007;32(2):252-5

7. Keramidas E, Brotherston M. Extensive metastasis to the hand from undiagnosed adenocarcinoma of the lung. Scand J Plast Reconstr Surg Hand Surg 2005;39:113-5. 